\title{
The Exploration into the Planning of Foreign Language Education in Guangxi Ethnic Areas in the Context of "the Belt and Road Initiative"
}

\author{
Hui Chen ${ }^{1,2, *}$ and Xianze $\mathrm{Wu}^{3}$
}

\author{
${ }^{1}$ Department of Chinese Language and Literature, Xiamen University \\ ${ }^{2}$ School of Foreign Languages, Changshu Institute of Technology \\ ${ }^{3}$ College of Foreign Studies, Guilin University of Technology \\ *Corresponding author.Email: chenhe813@126.com
}

\begin{abstract}
In the context of "The Belt and Road Initiative", in order to conduct language communication smoothly with other countries and build an international gateway to ASEAN, Guangxi ethnic areas need to implement the following foreign language education programs: 1. Foreign language courses should be set up in as late as secondary school stage instead of in primary school stage. 2. English education needs to be emphasized, but the situation should be changed that the English language predominates in the foreign language education for non-majors in college education. 3. The education of national languages of ASEAN countries should be targeted to more learners of different ages and majors. 4. The content and elements of Chinese culture should be included in the compilation and selection of foreign language teaching materials.
\end{abstract}

Keywords: "The Belt and Road Initiative", Guangxi Ethnic Areas, The Planning of Foreign Language Education.

\section{THE NECESSITY OF GUANGXI'S FOREIGN LANGUAGE EDUCATION PLANNING}

Deriving from "people's dissatisfaction with the current language situation", Language planning is an interdisciplinary study that is driven by realistic issues and cannot be separated from sociology, political science, linguistics, and pedagogy. Language planning, as an activity to consciously intervene in and adjust language development, developed rapidly after World War II. According to Ricento [1], the development of language planning can be divided into three stages: 1) 1950 s to late 1960 s. The emerging countries that gained independence after World War II established their own official languages legally, trying to weaken the influence and status of the languages of the colonial countries. 2) The early 1970 s to the late 1980 s. The consideration of language planning extends from the factors of language itself to the connection of language, society and politics. 3) After the mid-1980s. The connotation and extension of language planning continue to expand, and language diversity is valued and promoted. Since the 21 st century, thanks to the new international situation and international trends of thought, language planning research has entered the fourth stage, i.e. 4) The international development stage of language planning. In the first three stages of language planning, mother tongue planning is the main focus. Entering the 21 st century, with the development of world integration and global migration, especially since the "Belt and Road" initiative was put forward, the importance of foreign languages has become increasingly prominent. Therefore, in the fourth stage, an important feature of language planning is to pay attention to foreign language planning. As an important part of foreign language planning, foreign language education planning is a concrete manifestation of a country or region's language planning program in the field of foreign language education, also known as foreign language education policy.

Foreign languages cannot be inherited from generation to generation as mother tongues do. Therefore, developing foreign language education in a country or region mostly relies on the foreign language education of its citizens. The development of foreign 
language education is closely related to foreign language education planning. In recent years, foreign language education planning has received much attention from scholars. Especially in frontier and ethnic regions, bordering many countries, where the residents' languages and cultures are diverse, the language situation is more complex, and the foreign language education planning is more urgent and important [2][3].

The expansion of associating with other countries calls for smooth communication between different languages, which is the foundation of the "Belt and Road" and "interconnection". A language can transcend cultural barriers, communicate Chinese and foreign ideas, promote civilizational innovation, and build a "community with a shared future" along the "Belt and Road". Therefore, as an ethnic minority region mainly open to ASEAN, Guangxi needs to give full play to its geographical advantages, actively connect with ASEAN, and cultivate talents in all aspects who can communicate with ASEAN countries. However, for a long time, in the ethnic minority areas in Guangxi, like other areas in the country, English language education has dominated the foreign language education, leading to seriously unbalanced foreign language ecology. As an important gateway to the "Belt and Road", Guangxi ethnic regions need to re-examine its foreign language education plan to achieve "smooth communication between different languages" so as to build an international channel facing ASEAN.

\section{THE CURRENT SITUATION OF FOREIGN LANGUAGE EDUCATION IN ETHNIC AREAS IN GUANGXI AND THE LANGUAGE SITUATION OF ASEAN COUNTRIES}

The formal foreign language education in Guangxi can be divided into public foreign language education in colleges as well as secondary and primary schools, and professional foreign language education in colleges and universities. As far as public foreign language education is concerned, only English courses are offered, and English is a compulsory course. Most elementary students start English courses in the third grade. Elementary schools with better conditions will start English classes in the first or second grade ahead of schedule. For example, the affiliated elementary school of Guangxi Normal University for Nationalities in the border city of Chongzuo offers English classes in the second grade. The English course is offered from the third grade of elementary school to the second grade of university, which lasts for twelve years, the same as that of the national common language education. The national lingua franca here is mother tongue education for Han students, which is national lingua franca for ethnic minority students owning their native language.
In colleges in China, the number of foreign languages available to language majors is great, which depends on the geographic location of the college. In terms of regional characteristics, Guangxi can be roughly divided into the north and the south. The north is represented by Guilin and Liuzhou, where there is the most percentage of the Han people, whose language and customs are relatively close to the Southwest Mandarin district. The south is represented by Nanning, Chongzuo, Baise, etc., close to the ASEAN countries, where the minority with Zhuang people as the main body has the most percentage, who has some distinctive languages and customs. Colleges and universities in Guangxi is mainly located in northern Guangxi and southern Guangxi. The accessibility of languages available to foreign language majors is closely related to the geographical location and many foreign languages are available in colleges and universities in Guangxi. English is available in the most colleges and universities, followed by Japanese. The learning of Southeast Asian languages is offered in fewer universities in northern Guangxi. Guangxi Normal University, Guilin University of Technology, and Guilin University of Electronic Technology mainly offer English and Japanese, but no Southeast Asian languages. As a tourism college, Guilin Institute of Tourism offers a wide choice of English, Japanese, French, Spanish, Korean, Thai and other languages. In addition to common languages such as English and Japanese, colleges and universities in southern Guangxi also offer a variety of Southeast Asian languages. For example, Guangxi University applied for the major of Indonesian, Lao, Burmese, Malay, etc. in 2018. Only English and French are offered in the School of Foreign Languages in Guangxi University for Nationalities, while Vietnamese, Laotian, Thai, Cambodian, Burmese, Indonesian, Malay and other languages are offered in Southeast Asian Language and Culture Institute, where undergraduates, masters and doctoral students majoring in southeast Asian languages can be recruited, highlighting the status of Southeast Asian languages.

Connected with Vietnam by land and water, the Guangxi ethnic region is building the Beibu Gulf city cluster centered on the capital Nanning. Under the background of the "One Belt and One Road" initiative, Guangxi ethnic regions ushered in unprecedented development opportunities. Since 2004, the ChinaASEAN Expo has permanently settled in Nanning, which has attracted dignitaries, business and academic circles from ASEAN countries who attend or organize a forum there. The countries attending the Expo are mainly ten ASEAN countries, namely Malaysia, Indonesia, Thailand, Philippines, Singapore, Brunei, Vietnam, Laos, Myanmar and Cambodia.

The ten ASEAN countries have their own national language. For Malaysia, Singapore, and Brunei, Malay is the national language, and English is the common 
language, besides, the people from these countries are fairly proficient in English; For Philippines, Filipino is the national language, and English is the common language, besides, the Philippines are fairly proficient in English; The national language of Indonesia, Vietnam, Thailand, Laos, Myanmar and Cambodia is respectively Indonesian, Vietnamese, Thai, Lao, Burmese, and Cambodian, the first foreign language of which is English, which is not skillful, especially in Cambodia and Laos. In a word, English is the lingua franca in Malaysia, Singapore, Brunei, and the Philippines, and the people are proficient in English; English is a foreign language in the other six ASEAN countries, and the people are not skillful at English. Each country has its own national language. It should be paying attention to that Chinese is popular in Malaysia and Singapore. Besides, Lao, Thai, Vietnamese Taiyi, Nong, Tu language and Guangxi Zhuang language all belong to the Zhuang-Dai branch of the Zhuang-Dong family of the Sino-Tibetan language family, which have many similarities in the vocabulary and grammar.

\section{THE PLANNING OF FOREIGN LANGUAGE EDUCATION IN GUANGXI ETHNIC AREAS}

According to the current situation of foreign language education in Guangxi ethnic areas and the language conditions of ASEAN countries, we put up the following ideas for the foreign language education planning in Guangxi ethnic areas:

\subsection{Foreign Language Courses Should Be Postponed to Secondary Schools Instead of in Primary Schools.}

Guangxi is a concentrated area of ethnic minorities dominated by the Zhuang ethnic group, where there are many ethnic minorities. Many ethnic groups have their own mother tongue, and the Zhuang ethnic group even has its own script. China's language policy stipulates that Mandarin is the national lingua franca, and also the lingua franca for communication among all ethnic groups. Therefore, all ethnic minority students need to learn Mandarin. According to a survey, the Mandarin skill of ethnic minority students in Guangxi is still relatively poor. More than $50 \%$ of college students from an university in the border area of Guangxi failed to meet the requirements of the Putonghua ranking test when taking the first time test, which is far worse than that of mainland universities [4].

The language situation of the students in Guangxi ethnic areas is complicated. Living in a multi-ethnic area and in a multilingual environment from birth, they may acquire their own ethnic language, other ethnic minority languages, and Chinese dialects at the same time, which can be regarded as their first language.
When receiving formal school education in the elementary school, ethnic minority students begin to receive Chinese language education, whose phonetic system is their second language---Putonghua, which is very different from ethnic minority languages in three aspects: pronunciation, vocabulary, and grammar, and is also very different in pronunciation from the southern Chinese dialects in its area. Therefore, on the one hand, these students must practice spoken Putonghua, on the other hand, they have to receive written Putonghua education. The literacy education of Chinese characters is a heavy burden throughout the elementary school. Therefore, starting to learn English courses in the third grade of elementary school is a great challenge for them.

Language reflects culture. When receiving English language education, learners are subtly affected by English culture, which may bring a negative influence on children especially from ethnic minorities in Guangxi. Having not completed receiving a system of Chinese education, they have not established the cultural awareness of the Han nationality. The English education launched in the third grade of elementary school will seriously affect their ideology and national identity. Therefore, we hold that the start of English courses in the third grade of primary schools in Guangxi ethnic minority areas is too early and should be postponed to middle schools.

\subsection{English Education Should Be Kept Attaching Importance to, But It Is Necessary to Change the Situation that English Is the Only or the Primary Language Available in Public Foreign Language Teaching in Colleges and Universities.}

As one of the working languages of the United Nations, English is still the most influential language in the world, which is a common language in international politics and economics. English is a common language in Malaysia, Singapore, Brunei, and the Philippines and the first foreign language of the other six ASEAN countries. Therefore, playing an important role among ASEAN countries, the English language should be kept attaching importance to in the Guangxi minority areas.

However, in the context of "One Belt One Road", a good language ecology requires the coexist of multiple languages, which can maintain national security and promote economic development and cultural exchanges. The survival and development of living things need to maintain a good ecosystem, that is, mutual restriction, mutual dependence, and harmonious coexistence, so that the ecosystem is in a dynamic balance. Linguistic ecology believes that similar to living things, language needs a similar balanced ecosystem. Language reflects culture, and the imbalance of language ecology is the imbalance of cultural ecology [5]. A good language 
ecology for foreign language education requires a diversified language selection. English cannot be the only or the primary choice. Although English can also play a role in communication among ASEAN countries, the mother tongue can make people feel close. When we Chinese communicate with the people of ASEAN countries, it is a more sensible choice to select the mother tongue of ASEAN countries as a communication tool.

Therefore, in college foreign language teaching, English should not be the only choice, and other languages, such as French, Korean, and Thai and so on, should also be offered for students to select. After twelve years of English learning, students have reached a higher stage of mastery of English. It is due to the appearance of the plateau stage or fossilization stage of English learning that some students' English proficiency is still at a low stage. It will be fruitless to keep forcing them to learn English. Therefore, it is better to permit students to choose the appropriate language for studying on their own according to their career plans. In addition to English, colleges in Guangxi should offer national languages of ASEAN countries, such as Vietnamese, Thai, Indonesian, Lao, Burmese, Malay, Cambodian, etc., and the most influential language in the world Japanese, such as French, German, Spanish, etc. The diversification of foreign languages is conducive to China's national security and the development and dissemination of the culture.

\subsection{The Teaching of National Languages in ASEAN Countries Should is Offered to More Students Majoring in Different Disciplines.}

In recent years, more colleges in Guangxi have offered the courses in minor languages spoken by the people from ASEAN countries. For example, Guangxi University for Nationalities offers 7 ASEAN language courses: Vietnamese, Thai, Indonesian, Lao, Burmese, Malay, and Cambodian. In 2018, Guangxi University also announced to offer more ASEAN languages majors, who will soon own 6 ASEAN countries' language majors, including Vietnamese, Thai, Indonesian, Lao, Burmese, and Malay. There are also many universities offering Vietnamese, Thai and other languages, such as Guangxi Normal University for Nationalities, Baise University, Hechi University, etc. However, the courses of these ASEAN languages are only open to students majoring in foreign language in colleges.

We believe that ASEAN language courses can be offered to all kinds of students in universities and middle schools. In the middle school, Vietnamese, Lao, and Thai courses can be offered to Zhuang students, which come from the same primitive language as the Zhuang language. Their pronunciation, vocabulary, and grammar are relatively similar to that of the Zhuang language. It is quite easy for the Zhuang students to learn them. Based on some investigation, some scholars believe that the Zhuang students in Chongzuo bordering Vietnam are more willing to learn Vietnamese Taiyi, which is easy to learn and easy to use [6]. Colleges should offer ASEAN languages to all students. A smaller population of ASEAN countries may make it difficult for language learners majoring in ASEAN languages to find a position if the political and economic changes occur in the ASEAN countries. Therefore, colleges in Guangxi need to conduct some related research before recruiting language learners majoring in ASEAN languages. The number of students enrolled in various ASEAN language majors needs to be carefully weighted, and it is not advisable to blindly increase enrollment.

\subsection{The Compilation and Selection of Foreign Language Teaching Materials need to Increase the Content and Elements of Chinese Culture.}

The selection of foreign language teaching materials is an issue worth considering. Chinese people are keen to choose foreign original textbooks when learning foreign languages, and even the materials of textbooks published in China are nearly from foreign authors. It is true that language is a reflection of culture. To learn a foreign language, one must understand the culture of the country. Moreover, language education experts believe that learning a foreign language is to imitate the pronunciation, intonation, and even the way of thinking of the country's people. However, this issue deserves our deep consideration. What is the purpose of our learning foreign languages? on the one hand, the purpose is to master a language tool, to understand foreign cultures, and to learn advanced foreign technologies, on the other hand, the purpose is to spread the culture of China. Since there are not many foreigners learning our languages, one of our important tasks is to spread China's culture in foreign languages. Therefore, we need to change our strategy in the compilation and selection of foreign language teaching materials.

The textbook "Хи Guozhang English" published in China is a model of our English textbooks, most of the compiled content in which is related to life in China. However, since the 1990s, "Хu Guozhang English" has been criticized by many experts and scholars who say the language in the textbook is out of date and Chinglish. We believe that the reason why it is criticized is that our goal of learning English has gone the wrong way. In fact, English has more or less become a world language, which is owned by many other countries instead of only by the United States and the United Kingdom. English should become not only a tool for us to communicate with other countries in the world and learn advanced technologies from various countries, but also a tool for Chinese to spread China's brilliant culture and make 
understood by the world. English reflects Western culture, and English can also express Chinese culture. In recent years, the inclusion of the Chinese phrases "Daba (old aunt)" and "Tuhao (rich man)" with Chinese characteristics in English dictionaries is a proof that English can express Chinese culture. Therefore, we should have cultural self-confidence. In the compilation and selection of English textbooks, we should abandon the old thoughts of selecting materials in the past and increase more materials reflecting Chinese culture and Chinese life, which can bring two advantages. One advantage is that by introducing Chinese culture and Chinese life in English, leaners can introduce China to the world, eliminate other countries' misunderstandings about China, and increase China's international influence, the other advantage is that the learning of materials reflecting Chinese culture and Chinese life can resist and dispel the negative impact of English culture. Therefore, a substantial increase in the content of Chinese culture in English textbooks can eliminate the negative influence of English culture and enhance learners' cultural confidence.

In the compilation of teaching materials in other languages such as Japanese, Korean, and ASEAN languages, we also need to adopt the same strategy, that is, add materials that reflect Chinese culture and Chinese life, eliminate the negative influence and penetration of foreign culture, and teach learners to express Chinese culture and Chinese elements in foreign languages and increase China's influence in East Asia and ASEAN.

\section{CONCLUSION}

The interconnection of languages is the road and bridge to the "Belt and Road" "Community of Interests, Community of Responsibility, and Community of Destiny" [7]. Taking advantage of its geographical advantages, the Guangxi Zhuang Autonomous Region needs to lay the road and bridge of "language interconnection" and build an international channel towards ASEAN. The prerequisite for achieving "language interconnection" is to plan for good foreign language education. Guangxi has a large population of ethnic minorities with diverse languages and cultures. In terms of foreign language education planning, it is necessary to fully consider the language conditions of ethnic minorities and give full play to their advantages. The start of foreign language courses should be postponed to secondary schools instead of in primary schools. English education should be kept attaching importance to, but it is necessary to change the situation that English is the only or the primary language available in public foreign language teaching in colleges and universities. The teaching of National languages in ASEAN countries should be offered to more students majoring in different disciplines. The compilation and selection of foreign language teaching materials need to increase the content and elements of Chinese culture.

\section{ACKNOWLEDGMENTS}

The study is funded by the 2017 Annual Research Project of Guangxi Philosophy and Social Sciences Planning: Language Strategy Research in Guangxi under the background of "One Belt One Road" (Project Number: 17BYY003).

The study is also funded by the 2021 Annual Research Project of Philosophy and Social Sciences for Colleges in Jiangsu: Research on Language Attitudes of College Students in China during the New Era (Project Number: 2021SJA1408).

\section{REFERENCES}

[1] Ricento, Thomas. Historical and theoretical perspectives in language policy and planning $[\mathrm{J}]$. Journal of Sociolinguistics, 2000, (2).

[2] Diansheng Zhou \& Li Wang. Xinjiang Foreign Language Educational Situation and Adjustment Strategy. Journal of Foreign Languages, 2011(01): pp. 78-83.

[3] Bing Chen. Language Situation of the ASEAN Countries and Guangxi Foreign Language Strategy. Journal of Foreign Languages, 2012(01): pp. $77-$ 82.

[4] Xianze Wu \& Xiaorong Lin. Research on the Situation and Policy of Language Use in the Border Ethnic Areas of Guangxi. Journal of Chifeng University (Soc.Sci), 2015(10): pp. 188189.

[5] Bang JC\& Door J (Eds.). Language. Ecology and Society: A Dialectical Approach [C]. London and New York: Continuum, 2007.

[6] Xianze Wu \& Hui Chen. A Survey on Language Situation of Inhabitants of Border Area in Guangxi in the Context of "The Belt and Road Initiative". Guizhou Ethnic Studies, 2016(10): pp. 194-197.

[7] Lin $\mathrm{Xu} \&$ Zongfeng $\mathrm{Hu}$. Language Planning and Language Services for the Belt and Road Initiative. Journal of Northwest University (Philosophy and Social Sciences Edition), 2018(03): pp. 40-46. 